(2)

\title{
Effect of proton pump inhibitor use on Helicobacter pylori positivity and atrial fibrillation
}

\section{Kadri Atay'}

Omer Kaya ${ }^{2}$

'Istanbul University, Cerrahpasa School of Medicine, Division of Gastroenterology, ${ }^{2}$ Medipol University, Department of Internal Medicine, Istanbul, Turkey
This article was published in the following Dove Press journal:

Clinical Interventions in Aging

29 June 2015

Number of times this article has been viewed

\section{Dear editor}

We read with interest the report by Wang et al regarding the association between Helicobacter pylori infection and atrial fibrillation. ${ }^{1}$ One of our concerns about this well designed study is the lack of reporting of proton pump inhibitor (PPI) use in the patients and controls. It is well known that use of PPIs influences the results of some tests for H. pylori, including the urea breath test, which the authors used in their study. Notably, the frequency of $H$. pylori antibody positivity was similar between all three groups while $H$. pylori infection seems to be significantly more common in subjects with long-standing atrial fibrillation. More frequent use of PPIs may potentially explain the lower frequency of $\mathrm{H}$. pylori positivity in the control group and short-term atrial fibrillation group. Further, there are some recent reports indicating a protective effect of PPIs on the risk of atrial fibrillation, especially in people with gastroesophageal reflux disease. ${ }^{2}$ In conclusion, use of PPIs may have influenced some of the test results in this study, including the risk of atrial fibrillation.

\section{Disclosure}

The authors have no conflicts of interest to disclose in relation to this communication.

\section{References}

1. Wang DZ, Chen W, Yang S, et al. Helicobacter pylori infection in Chinese patients with atrial fibrillation. Clin Interv Aging. 2015;10:813-819.

2. Roman C, Bruley des Varannes S, Muresan L, Picos A, Dumitrascu DL. Atrial fibrillation in patients with gastroesophageal reflux disease: a comprehensive review. World J Gastroenterol. 2014;20: 9592-9599.
Correspondence: Omer Kaya Istanbul Medipol University, Esenler Hospital, Department of Internal Medicine, Esenler, Istanbul, P.B. 34230,

Turkey

Tel +905317930386

Email amerkaya@yahoo.com 


\section{Authors' reply}

De-Zhao Wang'

Wei Chen'

Song Yang ${ }^{2}$

Jun Wang ${ }^{3}$

Qun $\mathrm{Li}^{1}$

Qiang $\mathrm{Fu}^{2}$

Shi-Jing $\mathrm{Li}^{3}$

Bu-Xing Chen'

'Department of Cardiology, Beijing Tiantan Hospital, Capital Medical University, ${ }^{2}$ Department of Ultrasonography, Beijing Tiantan Hospital, Capital Medical University, ${ }^{3}$ Department of Cardiology, Beijing Mentougou District Hospital, Beijing, People's Republic of China

\section{Dear editor}

We are very glad to respond to the enquiry from Kadri Atay and Omer Kaya about use of PPIs in our subject. This study was a retrospective, cross-sectional analysis from a single center, and patients with gastrointestinal disease and those on PPI therapy before recruitment were excluded from the study.

\section{Disclosure}

The authors report no conflicts of interest in this communication.

\section{Correspondence: De-Zhao Wang}

Department of Cardiology, Beijing Tiantan Hospital, Capital Medical

University, No 6, Tiantan Xili, Dongcheng District, Beijing I00050,

People's Republic of China

Tel +86 I067096577

Email dezhao.w@I26.com

Dove Medical Press encourages responsible, free and frank academic debate. The content of the Clinical Interventions in Aging 'letters to the editor' section does not necessarily represent the views of Dove Medical Press, its officers, agents, employees, related entities or the Clinical Interventions in Aging editors. While all reasonable steps have been taken to confirm the content of each letter, Dove Medical Press accepts no liability in respect of the content of any letter, nor is it responsible for the content and accuracy of any letter to the editor.

\section{Publish your work in this journal}

Clinical Interventions in Aging is an international, peer-reviewed journal focusing on evidence-based reports on the value or lack thereof of treatments intended to prevent or delay the onset of maladaptive correlates of aging in human beings. This journal is indexed on PubMed Central, MedLine,
CAS, Scopus and the Elsevier Bibliographic databases. The manuscript management system is completely online and includes a very quick and fair peer-review system, which is all easy to use. Visit http://www.dovepress. com/testimonials.php to read real quotes from published authors. 